\title{
Fingolimod Therapy for Pediatric Relapsing-Remitting Multiple Sclerosis: A Real-Life Study
}

\author{
Ataklı Yineleyici Multipl Sklerozlu Çocuklarda Fingolimod Tedavisi: \\ Gerçek Yaşam Verisi
}

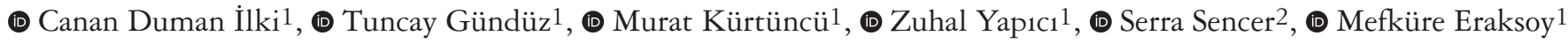
${ }^{1}$ Istanbul University, Istanbul Faculty of Medicine, Department of Neurology, Istanbul, Turkey 2Istanbul University, Istanbul Faculty of Medicine, Department of Radiology, Istanbul, Turkey

\begin{abstract}
Objective: Clinical studies in childhood multiple sclerosis (MS) are very limited compared with adults. Although first-line injection therapies are well tolerated in this patient group, there are difficulties in the long-term treatment of patients due to the difficulty and adverse effects of injections for children. Oral therapies are better tolerated for use and adverse effects compared with injection therapies. This study aimed to evaluate the clinical features and treatment outcomes of patients aged under 18 years with relapsing-remitting MS (RRMS) who received fingolimod treatment.

Materials and Methods: In this study, the clinical records of 22 patients with RRMS who received fingolimod treatment were examined. The patients were prospectively followed up between February 2015 and December 2018. The patients were evaluated in terms of relapse rate, Expanded Disability Status Scale (EDSS) scores, brain and cervical magnetic resonance imaging, and adverse effects before and after fingolimod treatment.

Results: The median age of $13(59 \%)$ female and 9 (41\%) male patients was 18 (range: 10-21) years. The median fingolimod treatment duration was 2.5 (range: 1.3-3.9) years. The median age of disease onset was 13 (range: 8-17) years. Fifteen patients (68\%) received a first-line treatment prior to fingolimod. The reason for switching to fingolimod was inefficacy in $33 \%$, adverse effects in $40 \%$, and both in $\% 27$ of patients. In $32 \%$ of patients, fingolimod was started as a first-line treatment. A total of three patients had recurrent relapses under treatment with fingolimod. The median annualized relapse rate (ARR) before fingolimod was 1.9 (range: 0.3-8.0), and the ARR with fingolimod was 0 (range: 0-2.0) (Wilcoxon's signed-rank test; $\mathrm{p}<0.001$ ). The median EDSS was 1.5 (range: 1.0-4.0) before fingolimod, and the EDSS after treatment was 1.5 (range: 1.0 to 5.0) (Wilcoxon's signed rank test; $\mathrm{p}=0.3$ ). None of the patients had any adverse effects during the first dose monitoring.
\end{abstract}

Conclusion: Our study shows that fingolimod is an effective and safe treatment alternative in childhood MS.

Keywords: Child and adolescent multiple sclerosis, fingolimod, real-world evidence

$\ddot{O} z$

Amaç: Çocukluk çağı multipl sklerozunda (MS) klinik çalışmalar erişkinlere göre çok sınırlıdır. Bu hasta grubunda birinci basamak enjeksiyon tedavileri her ne kadar iyi tolere edilseler de enjeksiyonun çocuklar için oluşturduğu zorluk ve yan etkiler nedeni ile hastaların uzun süreli tedavisinde zorluklar yaşanmaktadır. Enjeksiyon tedavileri ile karşılaştırıldı̆̆ında oral tedaviler kullanım ve yan etki açısından genel olarak daha iyi tolere edilmektedir. Bu çalışmanın amacı, 18 yaş altında fingolimod tedavisi almış olan ataklı-yineleyici MS'li (RRMS) hastaların klinik özelliklerini ve tedavi sonuçlarını değerlendirmektir.

Gereç ve Yöntem: Bu çalışmada fingolimod tedavisi almış 22 RRMS hastasının klinik kayıtları incelendi. Hastalar Şubat 2015 ve Aralık 2018 tarihleri arasında prospektif olarak takip edildi. Hastalar fingolimod tedavisi öncesi ve sonrası atak sıklığı, Genişletilmiş Engellilik Durum Ölç̧ŭi (EDSS) skorları, kraniyal ve servikal manyetik rezonans görüntülemeleri ve yan etkiler bakımından değerlendirildi.

Bulgular: Çalışmaya alınan 13 (\%59) kız ve 9 (\%41) erkek hastanın ortanca yaşları 18 (değişim aralığı: 10-21) idi. Hastaların fingolimod tedavisi aldıkları sürenin ortancası 2,5 (değişim aralı̆̆ı: 1,3-3,9) yıldı. Hastalık başlangıç yaşı ortancası 13 (değişim aralı̆̆ı: 8-17) idi. On beş hasta (\%68) fingolimod öncesinde birinci basamak tedavi almıştı. Daha önce tedavi almış olan hastaların \%33'ünde etkisizlik, \%40'ında yan etkiler, \%27'sinde ise yan etki ve etkisizlik sebebiyle fingolimoda geçildi. Hastaların \%32'sinde fingolimod ilk basamak tedavi olarak başlandı. Fingolimod tedavisi altında toplam üç hastada tekrarlayan ataklar izlendi. Hastaların fingolimod öncesinde yıllık atak sıklığı (ARR) ortancası 1,9 (değişim aralığ1: 0,3-8,0) iken fingolimod tedavisiyle ARR sıklığ 10 (değişim aralığı: 0-2,0) idi (Wilcoxon'ın işaretli sıra testi; p<0,001). Fingolimod öncesinde EDSS ortancası 1,5 (değişim aralığ1: 1,0-4,0) iken, tedavi sonrasındaki EDSS 1,5 (değişim aralığı: 1,0-5,0) idi (Wilcoxon'ın işaretli sıra testi; $\mathrm{p}=0,3$ ). İlk doz monitorizasyonu sırasında hastaların hiçbirinde yan etki izlenmedi.

Sonuç: Çalışmamız fingolimodun çocukluk çă̆ı MS'inde etkin ve güvenli bir tedavi alternatifi olduğunu desteklemektedir.

Anahtar Kelimeler: Çocuk ve ergen multipl skleroz, fingolimod, gerçek yaşam verisi

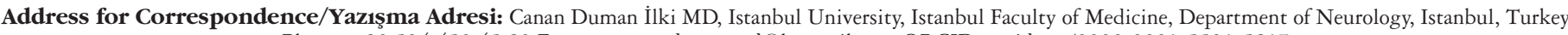
Phone: +90 5344504580 E-posta: cananduman-cd@hotmail.com ORCID: orcid.org/0000-0001-5531-5817

Received/Geliş Tarihi: 29.03.2019 Accepted/Kabul Tarihi: 31.07.2019

${ }^{\circ}$ Copyright 2020 by Turkish Neurological Society

Turkish Journal of Neurology published by Galenos Publishing House. 


\section{Introduction}

The prognosis of patients with multiple sclerosis (MS) in the pediatric age group ( $<18$ years) can vary considerably. Although most studies have shown that MS in childhood has more frequent relapses than in adults, some studies have demonstrated that the number of relapses, especially in the first five years, is lower than in adults, and that the Expanded Disability Status scale (EDSS) is more stable in the early period $(1,2,3)$.

Although the course of the disease is slower, the age of disability and secondary progression in pediatric patients with MS is approximately 10 years earlier than in adults, and the prognosis of patients is poorer than with adult MS $(3,4)$. In our previous study, which evaluated 143 patients who received their diagnosis at the age of 16 years in the Neurology Department of Istanbul University, it was observed that the number of relapses in the first five years was less frequent, especially under 12 years of age, but that the patients reached irreversible disability and secondary progression at a much earlier age than adults (5).

Despite the insufficiency in the number of placebo-controlled randomized trials, new-generation therapies used in adults are also used in pediatric patients. The efficacy, safety, patient compliance, and long-term adverse effects of these drugs in pediatric MS remain unclear in terms of how patients should be monitored $(6,7)$. Firstline treatment by injection is generally prefered in this age group; however, injection-related adverse effects and their low efficacy limit the use of these drugs. The European Drug Agency supports the use of injection therapies in patients aged over 12 years, although the United States Food and Drug Administration (FDA) has not yet approved for them for patients aged under 18 years (8). Although there is no randomized controlled double-blind study in terms of efficacy and safety, interferon beta and glatiramer acetate have been the most widely used first-line therapies in children to date.

Fingolimod treatment is more prominent in terms of both adverse effects and efficacy compared with injection therapies because it is better tolerated and is more effective than injection therapies $(9,10)$. Fingolimod binds to the sphingosine-1-phosphate receptor and prevents the transmigration of lymphocytes from lymph nodes. Peripheral lymphocyte depletion is believed to prevent damage to the central nervous system. However, recent findings support the effect of the drug through peripheral lymphocyte depletion and by altering the lymphocyte composition. Although fingolimod is generally well tolerated, it can rarely cause serious adverse effects such as bradycardia, lymphopenia, macular edema, infections, and elevated transaminases (11). Although these adverse effects are monitored by specific protocols, there is uncertainty as to how to monitor the pediatric population.

There are very few studies on fingolimod, a treatment that is expected to find more and more use in childhood in the coming years. Our study was planned to partially eliminate this lack of data.

\section{Materials and Methods}

Twenty-two patients aged under 18 years with relapsingremitting MS (RRMS) who were started on fingolimod treatment between February 2015 and December 2018 were included in the study. Patients were selected among patients diagnosed as having definite MS according to the 2010 McDonald and 2013 International Pediatric MS study group criteria. Age, sex, age of disease onset, age of initiation of fingolimod treatment, disease control therapy used before fingolimod treatment, MS Severity score (MSSS), and cerebrospinal fluid (CSF) findings were recorded.

The annualized relapse rate (ARR) before and after fingolimod treatment and EDSS scores of the patients were compared using Wilcoxon's signed-rank test. Statistical significance was accepted if the p-value was less than 0.05 .

\section{Results}

The data of $13(59 \%)$ girls and nine (41\%) boys were obtained. The median age of the patients in December 2018 was 18 (range: 10-21) years. The median age of disease onset was 13 (range: 8-17) years and the median duration of disease till the initiation of fingolimod treatment was 0.8 (range: $0.2-4.6$ ) years. The median MSSS value at the last follow-up examination was 3.3 (range: 1.88.4) (Table 1).

Ten patients underwent CSF examinations and all had positive CSF oligoclonal bands (pattern 2).

Fifteen $(68 \%)$ patients had previously received first-line treatment; three patients used glatiramer acetate and 12 patients used interferon beta. One patient had previously used both interferon beta and dimethyl-fumarate. The most common adverse

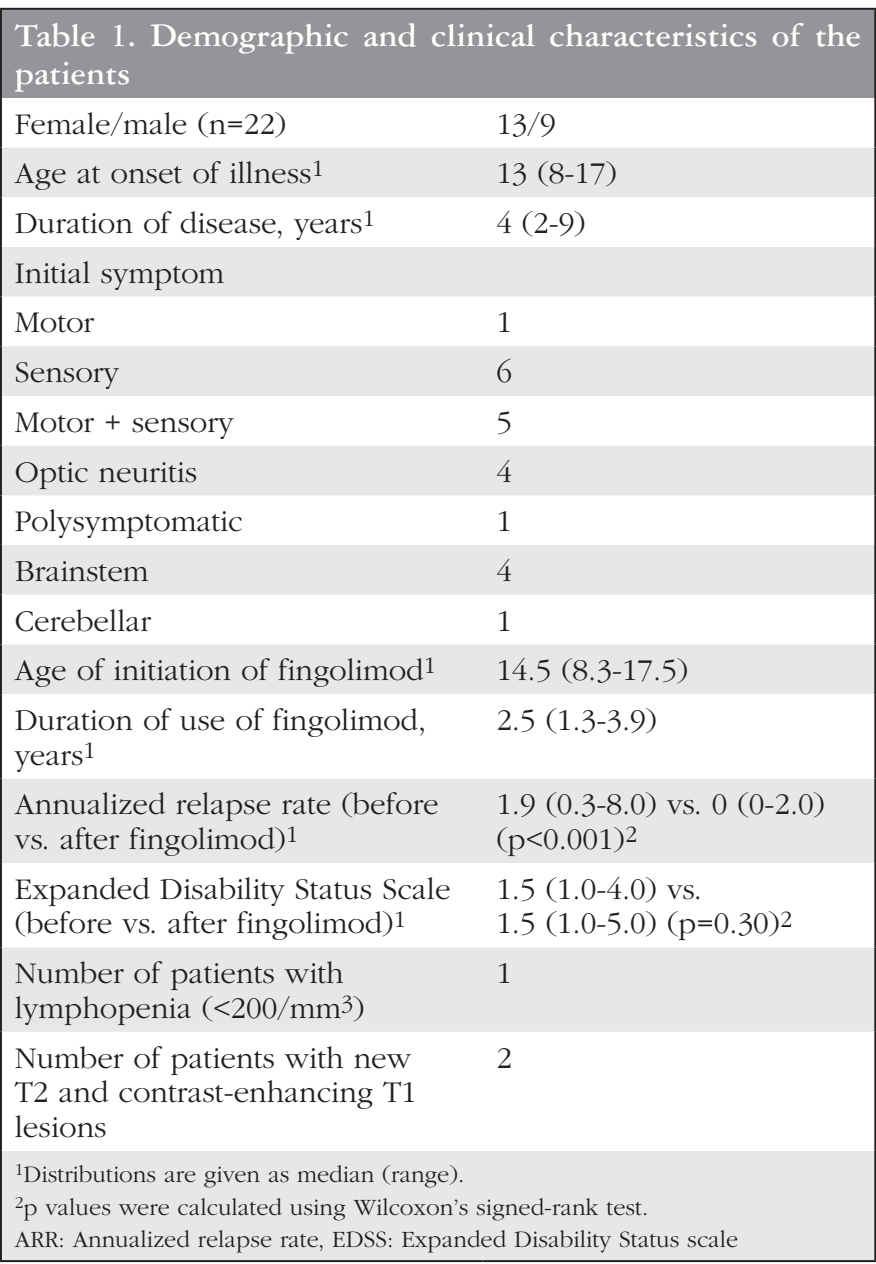


effects during injection treatments were injection site reaction, severe flu-like symptoms, and pathologic fatigue. The treatment was switched to fingolimod due to recurrent relapses in five patients $(33 \%)$, adverse effects in six $(40 \%)$ patients, and recurrent relapses and adverse effects in four $(27 \%)$ patients. Fingolimod was started as the first-line treatment in seven (32\%) patients.

During follow-up, only three patients had relapse. One of these patients was a nine-year-old girl who was treated with natalizumab following 1.4 years of fingolimod treatment for frequent relapses and radiologic progression. Although the other two patients had mild sensory attacks, fingolimod was continued.

The median ARR after fingolimod was 0 (range: 0-2), whereas the median ARR was 1.9 (range: 0.3-8) in the pre-treatment year (Wilcoxon's signed-rank test; $\mathrm{p}<0.001$ ). The median EDSS scores before and after fingolimod treatment were 1.5 (range: 1-4) and 1.5 (range: $1-5$ ), respectively (Wilcoxon's signed-rank test; $\mathrm{p}=0.3$ ).

No adverse effects were observed during the first dose monitoring. In a 13-year-old boy, the minimum heart rate at the first dose was 53/minute and 58/minute at the $6^{\text {th }}$ hour. During the follow-up of the same patient, bradycardia disappeared. In an eight-year-old male patient, the lymphocyte count decreased to $200 / \mathrm{mm}^{3}$, so his treatment was continued at $0.5 \mathrm{mg}$ every other day and the patient remained stable under this treatment. Except for this extreme example, it was observed that the lymphocyte count of the other patients was higher than $300 / \mathrm{mm}^{3}$. No macular edema was observed in any patients.

Patients had at least two brain and cervical spinal cord magnetic resonance imaging (MRIs). Except for two patients, no new lesions were detected in MRIs after fingolimod treatment. One of the patients who were radiologically active was an 18-year-old girl, and the other was a nine-year-old patient who had frequent clinical relapses and was switched to natalizumab treatment (Figure 1).

Fingolimod treatment was well tolerated and patients did not develop serious infections.

\section{Discussion}

Fingolimod is an effective and safe treatment for adult patients with MS $(8,9)$. Until recently, this treatment, which did not have sufficient data in pediatric patients with MS, was the first oral treatment approved by the FDA in May 2018 in pediatric patients by the PARADIGMS study completed in 2018 (12). Fingolimod treatment was approved only for adult patients in Turkey in April 2011 , but it still can be used in a limited group of patients through application for off-label use.

Many phase 2 and phase 3 studies are currently underway in children with RRMS. Only some of these have come to the publication stage. In one of these studies, FOCUS, dimethylfumarate was administered to 22 pediatric patients with MS. The eight-week and 24-week results of this phase 2 trial have been published recently (13). Accordingly, dimethyl-fumarate was found to be effective on MRI activity and clinical status, with an adverse effect profile similar to that of adults. Another ongoing trial is a trial with teriflunomide. The TERIKIDS trial, which included 165 patients, including Turkish patients with MS, was designed as a placebo-controlled, double-blind, randomized 96-week trial (14). In another ongoing study

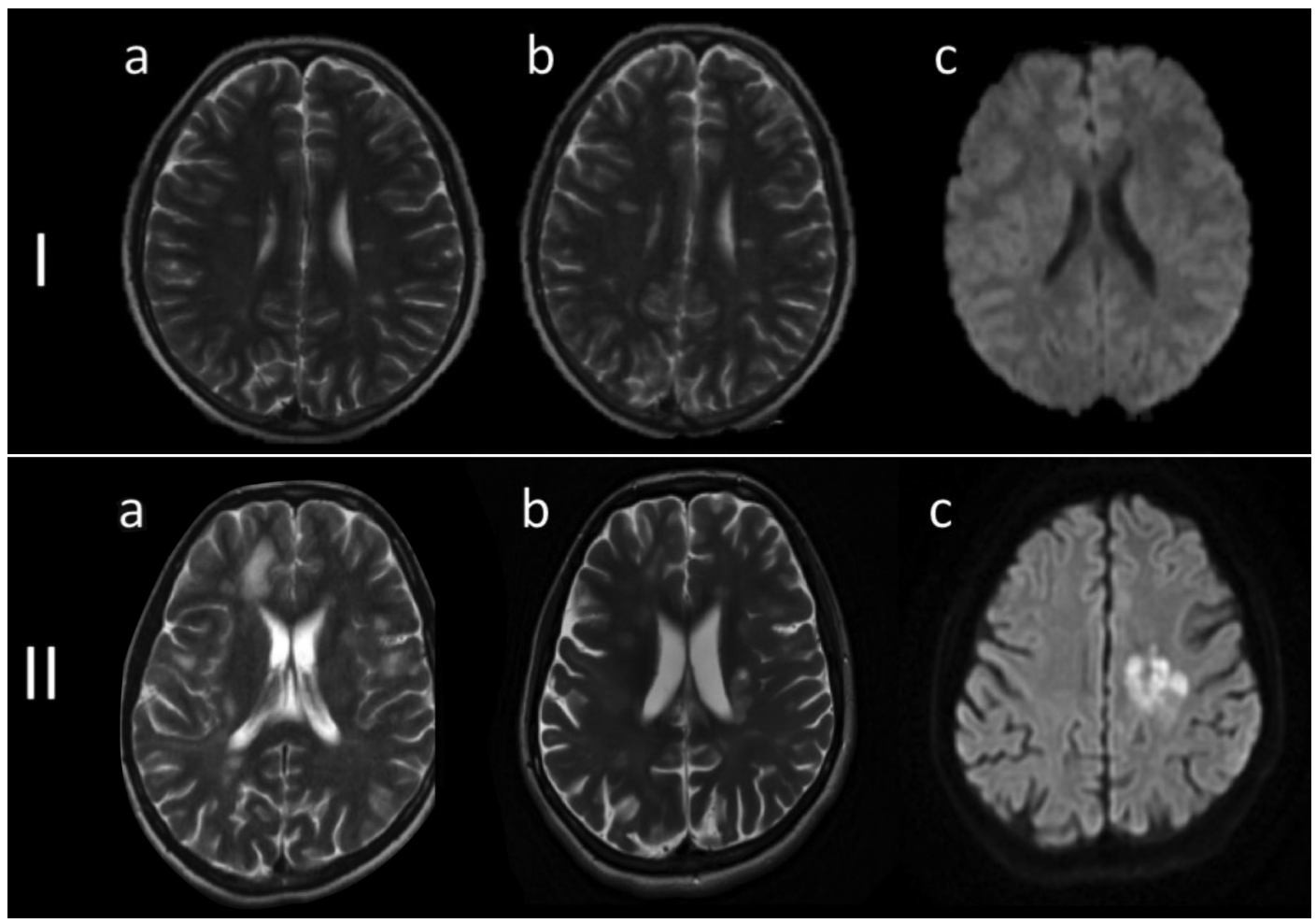

Figure 1. I) Magnetic resonance imaging (MRI) images before fingolimod use (a and b). One year after starting fingolimod, no new lesion was observed on control MRI (c). II) MRI images before fingolimod use (a and b). The treatment was switched to natalizumab due to new diffusion-restricting lesion in control MRI (c) 
(CONNECT trial), dimethyl-fumarate is compared with interferon beta-1a (15). This study is expected to be completed in 2020. Finally, the results of the LEMKIDS trial, a phase 3 trial involving 50 patients, are expected to be published by 2025 (16).

In the first placebo-controlled phase 3 trials of fingolimod, the FREEDOMS and FREEDOMS-2 trials, adult patients with MS were treated with doses of $0.5 \mathrm{mg}$ and $1.25 \mathrm{mg}$ for 24 months $(9,10)$. In the FREEDOMS study, it was observed that the ARR decreased by $54 \%$ at a low dose and $60 \%$ at a high dose compared with placebo in patients receiving active treatment. In addition to the improvement in all radiologic parameters, a $37 \%$ reduction in six-month disability progression and a $35 \%$ decrease in brain atrophy showed the efficacy of fingolimod. Although the FREEDOMS-2 study showed similar efficacy to the results of the FREEDOMS study, the effect of treatment on disability could not be demonstrated. Although there was no difference in efficacy between the two doses of fingolimod in both studies, it was observed that the adverse effect profiles were better in favor of the low dose. Fingolimod was compared with an active treatment, interferon beta-1a $30 \mu \mathrm{g}$, for the first time in the TRANSFORMS trial in 342 adult patients with MS. The ARR in the fingolimod group was $51 \%$ lower than in the placebo group. There was no difference between the drugs in terms of disability (17).

In the subgroup analysis of these three studies, fingolimod was found to be more effective in terms of frequency of relapses and MRI lesions when started early (disease duration $<3$ years) (18). Although there is some idea that the increased efficacy of fingolimod at early initiation may be related to age, immune system or early disease burden, there is no accepted clear explanation. In another subgroup analysis, the reduction in the mean ARR before 40 years of age was significantly higher than that after 40 years (64\% vs. $35 \%$ ) compared with placebo (19). Although these studies included patients in the 18-55 age range, these results in subgroup analyses may suggest that some drugs, such as fingolimod, may be more effective when started at an early age than in older patients.

The first study of fingolimod use in children aged under 18 years was reported in 2015 from Brazil. In this study, 17 patients with RRMS were treated for a mean of 8.6 months. Among these patients, it was reported that only one patient experienced a new relapse after 14 months of fingolimod use, and the other patients remained relapse-free and developed no serious adverse effects (20). In an observational study conducted in Germany in which natalizumab and fingolimod were given to high-activity pediatric patients with MS, there were 23 patients using fingolimod, seven of whom had previously used natalizumab and were switched to fingolimod. In the fingolimod group, the rate of relapse reduction was $75 \%$, with a reduction in the number of new T2 lesions of $81 \%$ and a decrease in the number of contrast-enhancing $\mathrm{T} 1$ lesions of $93 \%$ (21).

In a recent study on the use and outcome of diseaseregulating therapies introduced after 2005 in pediatric patients with MS, efficacy and short-term adverse effects were evaluated in patients receiving drugs such as fingolimod, natalizumab, dimethyl-fumarate, teriflunomide, daclizumab, rituximab, and alemtuzumab. Among these drugs, the most adverse effects were seen in dimethyl-fumarate users. The most common of these adverse effects were gastrointestinal symptoms and transient flushing, similar to adults. In a group of 1019 patients, 37 patients, 14 of whom were treatment naive, received fingolimod, and one patient had arrhythmia during the first dose. In general, the short-term adverse effects of fingolimod are not different from adults (22).

The PARADIGMS study, a single-phase 3 trial in which fingolimod was tested in pediatric MS studies, included 215 pediatric patients aged 10-18 years from a total of 25 countries (20). The $0.5 \mathrm{mg} / \mathrm{kg}$ dose of fingolimod $(0.25 \mathrm{mg} /$ day to those below $40 \mathrm{~kg}$ ) was compared with interferon beta-1a (intramuscular, once a week). The mean duration of drug use in the study was 18 months. At the end of the study, the mean ARR was 0.67 in the interferon beta group and 0.12 in the fingolimod group. In addition, $86 \%$ of the patients receiving fingolimod treatment for 24 months remained relapse-free. Compared with the patients receiving interferon, it was found that the number of new T2 lesions decreased by $53 \%$ and the number of new contrastenhancing T1 lesions by $66 \%$. There was a $77 \%$ difference in 3 -month disability progression. All adverse effects were $95 \%$ in interferon beta-1a group and $88 \%$ in fingolimod group. However, severe adverse effects (seizures, agranulocytosis, second-degree atrioventricular block, hypersensitivity) were found to be more frequent in the fingolimod group $(17.8 \%)$ than in the interferon beta-1a group $(9.3 \%)$.

Although there are methodologic differences between our study and other studies in which fingolimod was tried in pediatric RRMS, there are similarities in terms of results. Of the 22 patients included in our study, only three relapses were observed in the long term, suggesting that fingolimod is at least as effective as the treatment in the adult population. The fact that the mean followup period (2.7 years) of the patients included in our study was longer than that of the Brazilian cohort and PARADIGMS studies supports data showing that fingolimod is also effective in the long term. In addition, although the mean age of the patients in our study was similar to other studies, the presence of a patient aged under 10 years increases the importance.

When evaluated in terms of adverse effects, the absence of significant adverse effects except lymphopenia and first-dose bradycardia indicates that fingolimod is a safe treatment alternative in the pediatric population.

The fact that our study was an open-label, observational study, and the relatively small number of cases are the limitations of the study. The absence of a $0.25 \mathrm{mg}$ dose in Turkey and the drug being in the form of capsules caused the administered dosage to be the same as the adult dosage $(0.5 \mathrm{mg} /$ day $)$. However, in the PARADIGMS study, the dose of fingolimod was $0.25 \mathrm{mg}$ in children under $40 \mathrm{~kg}$. Therefore, in a child under the age of 10 years, the standard dose had to be reduced to $0.5 \mathrm{mg}$ every other day due to lymphopenia at the level of $200 / \mathrm{mm}^{3}$.

\section{Study Limitations}

To our knowledge, there are no data on the efficacy, compliance, and adverse effects of fingolimod use for more than two years in children with RRMS. In this age group, it is important to evaluate the long-term efficacy, safety, compliance, and adverse effects of fingolimod (such as macular edema, effects on the developing immune system). 


\section{Conclusion}

In conclusion, this open-label observation study reveals that fingolimod is a safe, highly therapeutic, and effective treatment option in children with RRMS and can be used as a first-line treatment in pediatric patients with high clinical activity. However, it is clear that larger, prospective and long-term real-life studies are needed to assess the safety and efficacy of fingolimod in children.

\section{Ethics}

Ethics Committee Approval: The ethics committee approval is not obtained as the study data is retrospective and belongs to the prior to 2020 .

Informed Consent: Retrospective study.

Peer-review: Externally peer-reviewed.

\section{Authorship Contributions}

Surgical and Medical Practices: M.E., M.K., Z.Y., T.G., C.D.İ., Concept: M.E., M.K., C.D.İ., Design: M.E., M.K., C.D.İ., Data Collection or Processing: M.E., C.D.İ., Analysis or Interpretation: M.E., M.K., C.D.İ., Literature Search: C.D.İ., S.S., Writing: C.D.İ. Conflict of Interest: No conflict of interest was declared by the authors.

Financial Disclosure: The authors declared that this study received no financial support.

\section{References}

1. Simone IL, Carrara D, Tortorella C, et al. Course and prognosis in early-onset MS: Comparison with adult-onset forms. Neurology 2002;59:1922-1928.

2. Banwell B, Ghezzi A, Bar-Or A, Mikaeloff Y, Tardieu M. Multiple sclerosis in children: clinical diagnosis, therapeutic strategies, and future directions. Lancet Neurol 2007;6:887-902.

3. Renoux C, Vukusic S, Mikaeloff Y, et al; Adult Neurology Departments KIDMUS Study Group. Natural History of Multiple Sclerosis with Childhood Onset. N Engl J Med 2007;356:2603-2613.

4. Banwell BL, Anderson PE. The cognitive burden of multiple sclerosis in children. Neurology 2005;64:891-894.

5. Duman İlki C. Çocukluk Yaş Başlangıçlı Demiyelinizan Hastalıklarda Klinik ve Demografi Özellikler ve Anti MOG Antikorlarının Prognoz Üzerindek Etkilerinin Belirlenmesi (Uzmanlık Tezi), İstanbul, İstanbul Üniversitesi, 2018.

6. Ghezzi A, Banwell B, Boyko A, et al. The management of multiple sclerosis in children : a European view. Mult Scler 2010;16:1258-1267.

7. Ghezzi A, Amato MP, Makhani N, Shreiner T, Gärtner J, Tenembaum S. Pediatric multiple sclerosis: Conventional first-line treatment and general management. Neurology 2016;87(9 Suppl 2):S97-S102.
8. Krupp LB, Tardieu M, Amato MP, et al; International Pediatric Multiple Sclerosis Study Group. International Pediatric Multiple Sclerosis Study Group criteria for pediatric multiple sclerosis and immune-mediated central nervous system demyelinating disorders : revisions to the 2007 definitions. Mult Scler 2013;19:1261-1267.

9. Calabresi PA, Radue EW, Lublin FD. Safety and e ffi cacy of fi ngolimod in patients with relapsing-remitting multiple sclerosis (FREEDOMS II): a double-blind, randomised, placebo-controlled, phase 3 trial. Lancet Neurol 2014;13:545-556.

10. Kappos L, Radue EW, O'Connor P, et al; FREEDOMS Study Group. A Placebo-Controlled Trial of Oral Fingolimod in Relapsing Multiple Sclerosis. N Engl J Med 2010;362:387-401.

11. Altunrende B, Birday E, Kasap M. Relapsing Remitting Multipl Skleroz Tedavisinde Fingolimod Kullanım. Turk J Neurol 2017;23:176-185.

12. Roxburgh RH, Seaman SR, Masterman T, et al. Multiple sclerosis severity score: Using disability and disease duration to rate disease severity. Neurology 2005;64:1144-1151.

13. Chitnis T. PARADIGMS: a randomized double-blind study of fingoliimod versus interferon B-1a in pediatric multiple sclerosis' ECTRIMS online library. 202640, 2017.

14. Alroughani R, Das R, Penner N, Pultz J, Taylor C, Eraly S. Safety and Efficacy of Delayed-Release Dimethyl Fumarate in Pediatric Patients With Relapsing Multiple Sclerosis (FOCUS). Pediatr Neurol 2018;83:19-24.

15. Efficacy, safety and pharmacokinetics of Teriflunomide in Pediatric Patients With Relapsing Forms of Multiple Sclerosis (TERIKIDS). Accessed date: 6/20/2018. Available from: https://www.clinicaltrials.gov/ct2/show/ NCT02201108? cond $=$ pediatric + multiple + sclerosis $\&$ draw $=2 \&$ rank $=16$

16. Phase 3 efficacyand safetystudy of BG00012 in pediatricsubjects with relapsing remitting multiple sclerosis(RRMS)(CONNECT). https://www.clinicaltrials gov/ct2/show/NCT02283853 ? cond = pediatric + multiple + sclerosis\&draw $=$ $4 \&$ rank $=21$. Accessed June 202018

17. A study to evaluate efficacy, safety, and tolerability of alemtuzumab in pediatric patients with RRMS with disease activ- ity on prior DMT (LemKids). https://clinicaltrials.gov/ct2/show/NCT03368664. Accessed June 202018.

18. Cohen JA, Barkhof F, Comi G, et al; TRANSFORMS Study Group. Oral Fingolimod or Intramuscular Interferon for Relapsing Multiple Sclerosis. N Engl J Med 2010;362:402-415.

19. Agius M, Meng X, Chin P, Grinspan A, Hashmonay R. Fingolimod Therapy in Early Multiple Sclerosis : An Efficacy Analysis of the TRANSFORMS and FREEDOMS Studies by Time Since First Symptom. CNS Neurosci Ther 2014;20:446-451.

20. Derfuss T, Ontaneda D, Nicholas J, Meng X, Hawker K. Relapse rates in patients with multiple sclerosis treated with fingolimod: subgroup analyses of pooled data from three phase 3 trials. Mult Scler Relat Disord 2016;8:124130.

21. Fragoso YD, Alves-Leon SV, Barreira AA, et al. Pediatric Neurology Fingolimod Prescribed for the Treatment of Multiple Sclerosis in Patients Younger Than Age 18 Years. Pediatr Neurol 2015;53:166-168.

22. Huppke P, Huppke B, Ellenberger D, et al. Therapy of highly active pediatric multiple sclerosis. Mult Scler 2019;25:72-80. 